\title{
FRACTURE ENERGY AND FATIGUE STRENGTH OF UNREINFORCED CONCRETE BEAMS AT NORMAL AND LOW TEMPERATURES
}

\author{
ULF OHLSSON, PER ANDERS DAERGA and LENNART ELFGREN \\ Division of Structural Engineering, Luleå University of Technology, S-951 87 Luleå, Sweden
}

\begin{abstract}
Results are presented from tests where the fracture energy and the fatigue strength have been determined for unreinforced concrete beams. The tests were performed at temperatures between +20 and $-35^{\circ} \mathrm{C}$ with concrete with compressive strength varying between 25 and $100 \mathrm{MPa}$.
\end{abstract}

\section{INTRODUCTION}

A SUBSTANTIAL part of the concrete structures in the world are built in areas with low winter temperatures. The temperature strongly influences the material properties. Experiments performed at Luleå University of Technology[1-7] have been focused on fracture mechanics properties at low temperatures. Ordinary concrete, high strength concrete, lightweight and fibre reinforced concrete have been tested.

\section{TEST SPECIMEN}

Four concrete qualities $\mathrm{C} 25, \mathrm{C} 40, \mathrm{LC} 45$ and $\mathrm{C} 100$ have been used in the investigations (Table 1). Unreinforced concrete beams and cubes have been cast in steel moulds. The beams had the dimensions $500 \times 80 \times 50 \mathrm{~mm}$ in the first two series. In the following series they had the dimensions $840 \times 100 \times 100 \mathrm{~mm}$ according to RILEM's recommendations[8]. After the casting the test specimens were covered with plastic film and kept wet. The forms were removed after three days and the specimens were then cured in water. At the end of the curing time notches were sawn in the beams $(10 \mathrm{~mm}$ in the small beams and $50 \mathrm{~mm}$ in the other beams).

The tests were carried out in a climate chamber equipped with mobile test rigs (Fig. 1). Series $\mathrm{C} 40 \mathrm{~A}-\mathrm{C}$ were tested with a $130 \mathrm{kN}$ servohydraulic Instron actuator. The other series were tested in an ordinary $200 \mathrm{kN}$ hydraulic press. The midspan deflection were measured with two LVDTs (Linear Variable Differential Transducers) and the load was registered with a $20 \mathrm{kN}$ loadcell.

Most of the beams were tested when they had dried in the laboratory for about a week. They then had a moisture content of about $5 \%$ (i.e. the concrete lost $5 \%$ of its weight if it spent $72 \mathrm{~h}$ in an oven at $+105^{\circ} \mathrm{C}$ ). In two series also wet beams where tested (i.e. the beams were taken from a water basin and were kept sealed in plastic wrappings in the climate room up to testing).

Concrete compressive strength $f_{\mathrm{cc}}$ and concrete tensile splitting strength $f_{\text {cspl }}$ from the tests are given in Tables 2 and 3.

\section{FRACTURE ENERGY}

Typical load-deformation diagrams for tests with $\mathrm{C} 100$ concrete under varying temperatures are given in Fig. 2. Fracture energy values $G_{\mathrm{FE}}$ derived from the experiments according to [8] are given in Fig. 3 and in Table 4.

The results show that the fracture energy $G_{\mathrm{FE}}$ increases considerably when concrete with some moisture in it is tested at low temperatures. This increase may be attributed to the load-carrying capacity the ice skeleton develops when the water in the pore system freezes. Similar effects have been observed in tests on the compressive and tensile strength by several investigators, see e.g. [7] and [9]. Fracture energy at low temperatures has earlier only been studied by Elices, Planas and Matarana[10] and by Körmeling[11]. Elices et al. found that the fracture energy increased in a 
Table 1. Concrete mixes

\begin{tabular}{|c|c|c|c|c|c|c|}
\hline $\begin{array}{c}\text { Concrete } \\
\text { type } \\
\text { Reference } \\
\text { number }\end{array}$ & $\begin{array}{c}\text { Cement } \\
\left(\mathrm{kg} / \mathrm{m}^{3}\right)\end{array}$ & $\frac{w}{c+s}$ & $\frac{s}{c}$ & $\begin{array}{c}\text { Max } \\
\text { aggregate } \\
\text { size } \\
(\mathrm{mm})\end{array}$ & $\begin{array}{c}\text { Age } \\
\text { at } \\
\text { testing } \\
\text { (days) }\end{array}$ & Notes \\
\hline $\mathrm{C} 25[1]$ & 248 & 0.60 & 0 & 8 & 28 & (1) \\
\hline $\mathrm{C} 40[1]$ & 378 & 0.49 & 0 & 8 & 28 & (2) \\
\hline $\begin{array}{r}\text { C40A [2] } \\
\text { B [2] } \\
\text { C [2] }\end{array}$ & $\begin{array}{l}372 \\
372 \\
372\end{array}$ & $\begin{array}{l}0.48 \\
0.48 \\
0.48\end{array}$ & $\begin{array}{l}0 \\
0 \\
0\end{array}$ & $\begin{array}{l}16 \\
16 \\
16\end{array}$ & $\begin{array}{l}39 \\
42\end{array}$ & $\begin{array}{l}(3) \\
(4) \\
(5)\end{array}$ \\
\hline LC45 [3] & 375 & 0.35 & 0.10 & 12 & $44-46$ & (6) \\
\hline $\mathrm{Cl} 100[4]$ & 470 & 0.31 & 0.15 & 8 & 49 & (7) \\
\hline
\end{tabular}

Notes: $w=$ water, $c=$ cement, $s=$ silica $\left[\mathrm{kg} / \mathrm{m}^{3}\right]$. (1) Air entrainer $74.4 \mathrm{~g} / \mathrm{m}^{3}$, moisturc content $6.4 \%$ at testing. (2) Air entrainer $113.4 \mathrm{~g} / \mathrm{m}^{3}$, moisture content $5.2 \%$ at testing. (3) Air entrainer $50 \mathrm{~g} / \mathrm{m}^{3}$, moisture content $5.0 \%$ at testing. (4) Air entrainer $39.1 \mathrm{~g} / \mathrm{m}^{3}$. (5) Air entrainer $39.1 \mathrm{~g} / \mathrm{m}^{3}$, quick hardening cement. (6) Leca $4-8 \mathrm{~mm} 300 \mathrm{~kg} / \mathrm{m}^{3}$, Leca $8-12 \mathrm{~mm} 300 \mathrm{~kg} / \mathrm{m}^{3}$, plasticizer $3.75 \mathrm{~kg} / \mathrm{m}^{3}$ (Rescon P). (7) Plasticizer $10 \mathrm{~kg} / \mathrm{m}^{3}$.

Table 2. Concrete compressive strength $f_{\mathrm{cc}}[\mathrm{MPa}]$ at varying temperatures

\begin{tabular}{|c|c|c|c|c|c|c|c|c|c|}
\hline $\begin{array}{c}\text { Concrete } \\
\text { type } \\
\text { Reference } \\
\text { number }\end{array}$ & $\begin{array}{c}T \\
(\mathrm{C})\end{array}$ & $\begin{array}{c}f_{\mathrm{c}} \\
(\mathrm{MPa})\end{array}$ & $\frac{n}{-}$ & $\begin{array}{c}T \\
(\mathrm{C})\end{array}$ & $\begin{array}{c}f_{\infty} \\
(\mathrm{MPa})\end{array}$ & $\underline{n}$ & $\begin{array}{c}T \\
(\mathrm{C})\end{array}$ & $\begin{array}{c}f_{\mathfrak{c}} \\
(\mathrm{MPa})\end{array}$ & $\stackrel{n}{-}$ \\
\hline $\mathrm{C} 25[1]$ & & & & & & & +20 & 30.3 & 3 \\
\hline $\mathrm{C} 40[1]$ & & & & & & & +20 & 43.5 & 3 \\
\hline $\begin{array}{r}\mathrm{C} 40 \mathrm{~A}[2] \\
\mathrm{B}[2] \\
\mathrm{C}[2]\end{array}$ & & & & & & & $\begin{array}{l}+20 \\
+20 \\
+20\end{array}$ & $\begin{array}{l}52.3 \\
53.1 \\
64.0\end{array}$ & $\begin{array}{l}3 \\
3 \\
3\end{array}$ \\
\hline $\begin{array}{r}\text { LC45D [3] } \\
\text { W [3] }\end{array}$ & $\begin{array}{l}-30 \\
-30\end{array}$ & $\begin{array}{r}84.1 \\
>88.9\end{array}$ & 1 & $\begin{array}{l}-15 \\
-15\end{array}$ & $\begin{array}{l}80.6 \\
79.4\end{array}$ & $\begin{array}{l}2 \\
2\end{array}$ & $\begin{array}{l}+20 \\
+20\end{array}$ & $\begin{array}{l}69.7 \\
59.7\end{array}$ & $\begin{array}{l}1 \\
3\end{array}$ \\
\hline $\begin{array}{r}\mathrm{Cl} 100 \mathrm{D}[4] \\
W[4]\end{array}$ & $\begin{array}{l}-30 \\
-30\end{array}$ & $\begin{array}{r}>108 \\
97\end{array}$ & 1 & $\begin{array}{l}-15 \\
-15\end{array}$ & $\begin{array}{r}104 \\
94\end{array}$ & 1 & $\begin{array}{l}+18 \\
+18\end{array}$ & $\begin{array}{r}103 \\
96\end{array}$ & $\begin{array}{l}2 \\
2\end{array}$ \\
\hline
\end{tabular}

relation 3 to 1 on lowering the temperature from 20 to $-170^{\circ} \mathrm{C}$. We found increases of $20-100 \%$ when we lowered the temperature from +20 to $-30^{\circ} \mathrm{C}$.

\section{FATIGUE STRENGTH}

Cyclic tests were performed with constant amplitudes at several load levels $P_{\max } / P_{0}$, where $P_{\max }$ is the maximum load in a cyclic test and $P_{0}$ is the peak load in a corresponding test with a montonically increasing load. A saw-tooth type of waveform was used in the cyclic tests with a frequency of $1 / 15 \mathrm{~Hz}$ and a minimum load $P_{\min }$ of $0.1 \mathrm{kN}$. Typical results of a test are given in Fig. 4. In Table 5 all the tests are summarized. The test results are also shown in the form of Wöhler diagrams in Figs 5-7.

Table 3. Concrete tensile splitting strength $f_{\mathrm{cspl}}[\mathrm{MPa}]$ at varying temperatures

\begin{tabular}{|c|c|c|c|c|c|c|c|c|c|}
\hline $\begin{array}{l}\text { Concrete } \\
\text { type } \\
\text { Reference } \\
\text { number }\end{array}$ & $\begin{array}{c}T \\
\left({ }^{\circ} \mathrm{C}\right)\end{array}$ & $\begin{array}{c}f_{\mathrm{cspl}} \\
(\mathrm{MPa})\end{array}$ & $\frac{n}{-}$ & $\begin{array}{c}T \\
\left({ }^{\circ} \mathrm{C}\right)\end{array}$ & $\begin{array}{c}f_{\mathrm{cspl}} \\
(\mathrm{MPa})\end{array}$ & $\underline{n}$ & $\begin{array}{c}T \\
\left({ }^{\circ} \mathrm{C}\right)\end{array}$ & $\underset{(\mathrm{MPa})}{f_{\mathrm{cppl}}}$ & $n$ \\
\hline $\begin{array}{r}\mathrm{C} 40 \mathrm{~A}[2] \\
\mathrm{B}[2] \\
\mathrm{C}[2]\end{array}$ & $\begin{array}{l}-24 \\
-24 \\
-24\end{array}$ & $\begin{array}{l}5.4 \\
6.3 \\
-\end{array}$ & $\begin{array}{r}3 \\
6 \\
-\end{array}$ & & & & $\begin{array}{l}+20 \\
+20 \\
+20\end{array}$ & $\begin{array}{l}4.2 \\
4.0 \\
3.8\end{array}$ & $\begin{array}{l}3 \\
3 \\
5\end{array}$ \\
\hline $\begin{array}{r}\text { LC45D [3] } \\
W[3]\end{array}$ & $\begin{array}{l}-30 \\
-30\end{array}$ & $\begin{array}{l}6.1 \\
7.4\end{array}$ & $\begin{array}{l}3 \\
2\end{array}$ & $\begin{array}{l}-15 \\
-15\end{array}$ & $\begin{array}{l}6.0 \\
7.2\end{array}$ & $\begin{array}{l}2 \\
2\end{array}$ & $\begin{array}{l}+20 \\
+20\end{array}$ & $\begin{array}{l}4.8 \\
4.9\end{array}$ & $\begin{array}{l}2 \\
1\end{array}$ \\
\hline $\begin{array}{r}\text { ClooD [4] } \\
\text { W [4] }\end{array}$ & $\begin{array}{l}-30 \\
-30\end{array}$ & $\begin{array}{l}8.4 \\
9.0\end{array}$ & $\begin{array}{l}3 \\
2\end{array}$ & $\begin{array}{l}-15 \\
-15\end{array}$ & $\begin{array}{l}7.7 \\
7.5\end{array}$ & $\begin{array}{l}2 \\
2\end{array}$ & $\begin{array}{l}+18 \\
+18\end{array}$ & $\begin{array}{l}5.8 \\
7.1\end{array}$ & $\begin{array}{l}6 \\
5\end{array}$ \\
\hline
\end{tabular}




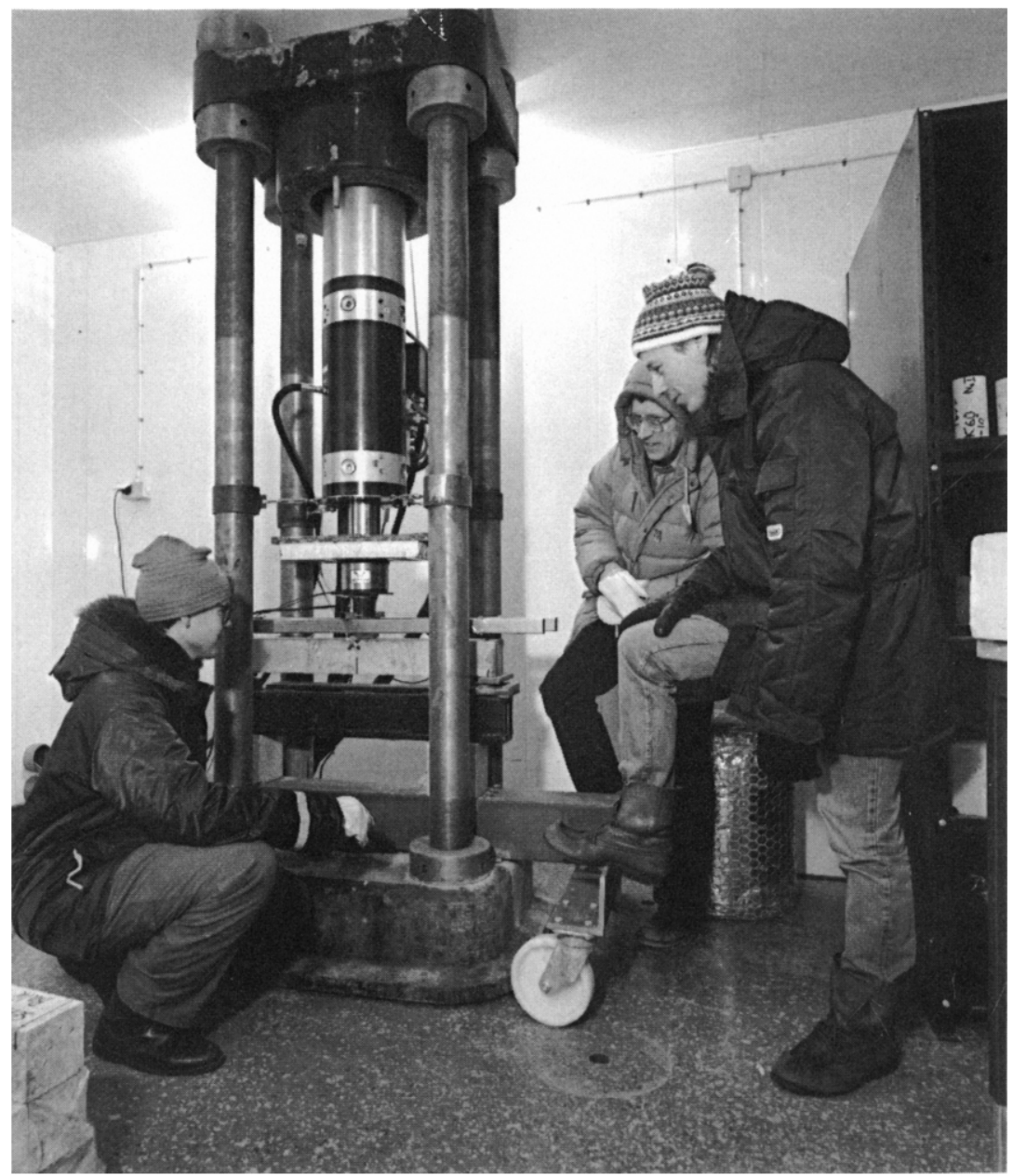

Fig. 1. Test arrangement in climate room $[2,6]$. 


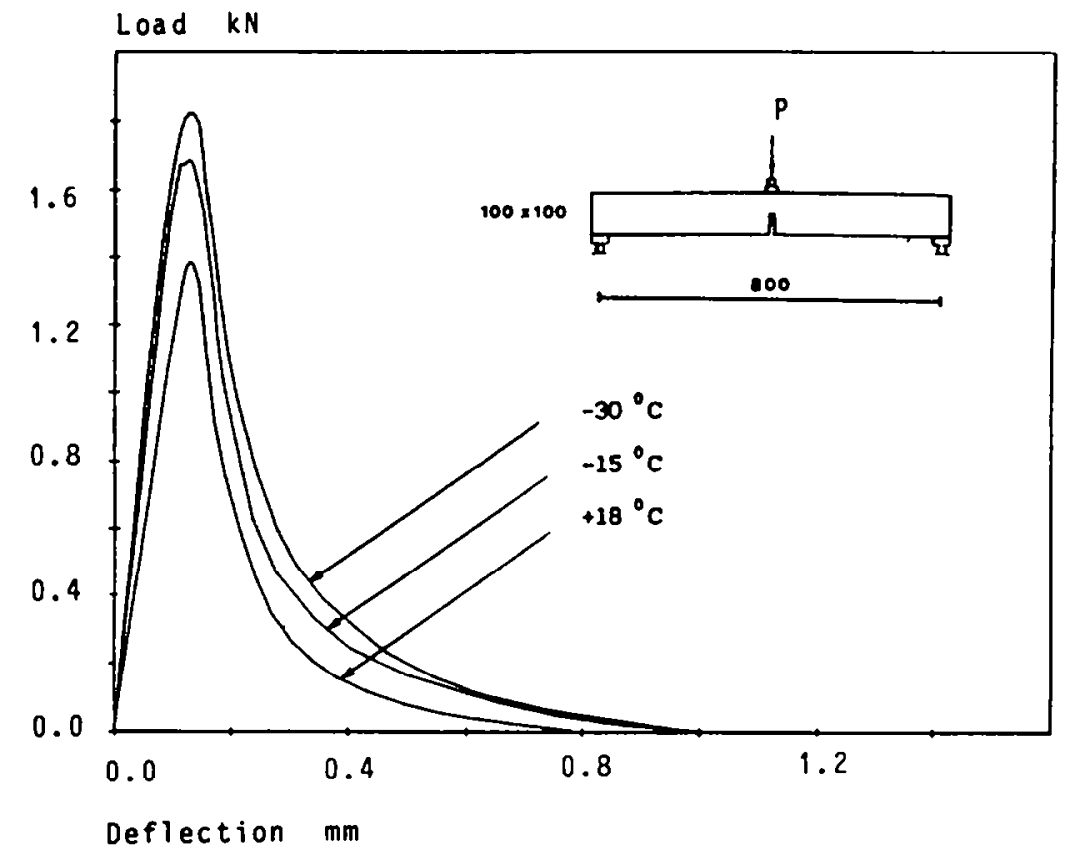

Fig. 2. Load-deflection curves for C100 at varying temperatures[4].

Figure 6 indicates that the fatigue strength increases when the temperature is lowered. The scatter in these results is larger than the scatter in tests performed at ordinary temperature. One of the explanations to the raised fatigue strength at low temperatures can be found in the mechanisms of crack propagation during fatigue loading. A fatigue failure often shows a more extensive crack pattern than a static failure. The concrete is more "cracked" after a fatigue failure. This cracking occurs in the many imperfections, pores and interface zones of the aggregate particles. In a frozen concrete with high moisture content large parts of the pore system are filled with ice.

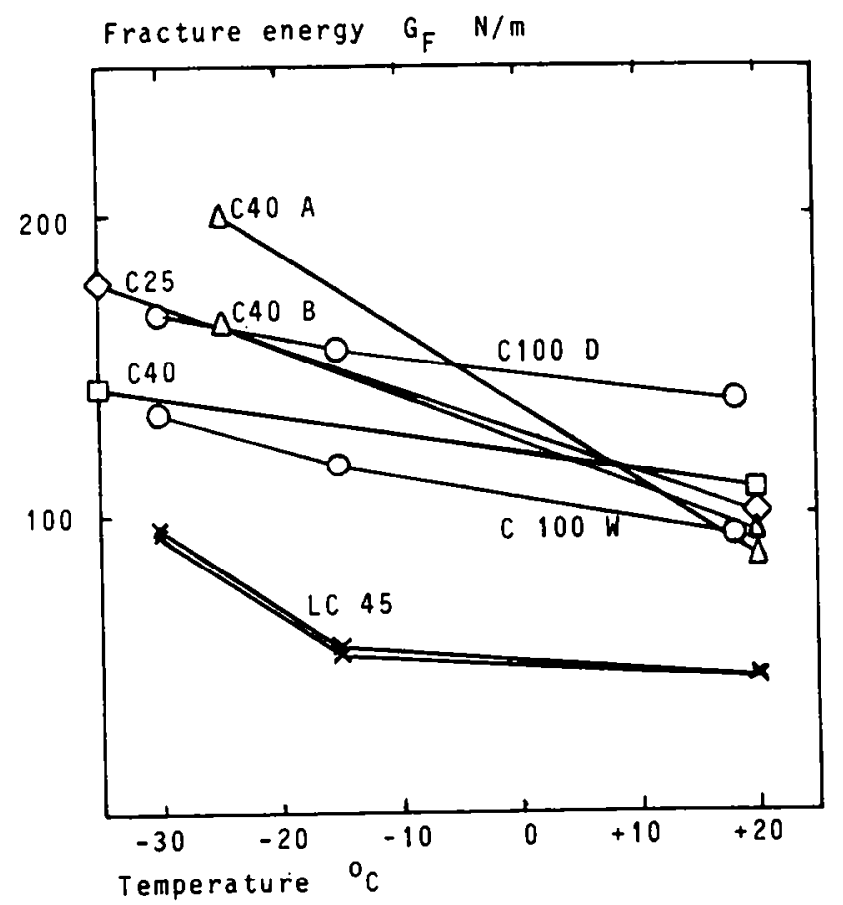

Fig. 3. Experimentally determined fracture energy $G_{\mathrm{FE}}$ as function of temperature for different concrete qualities $[2,7]$. 
Table 4. Experimentally determined fracture energy $G_{\mathrm{FE}}[\mathrm{N} / \mathrm{m}]$ at varying temperatures

\begin{tabular}{|c|c|c|c|c|c|c|c|c|c|c|c|c|}
\hline $\begin{array}{l}\text { Concrete } \\
\text { type } \\
\text { Reference } \\
\text { number }\end{array}$ & $\begin{array}{c}T \\
\left({ }^{\circ} \mathrm{C}\right)\end{array}$ & $\begin{array}{c}G_{\mathrm{FE}} \\
(\mathrm{N} / \mathrm{m})\end{array}$ & $\stackrel{s}{(\mathrm{~N} / \mathrm{m})}$ & $\stackrel{n}{-}$ & $\begin{array}{c}T \\
\left({ }^{\circ} \mathrm{C}\right)\end{array}$ & $\begin{array}{c}G_{\mathrm{FE}} \\
(\mathrm{N} / \mathrm{m})\end{array}$ & $\begin{array}{c}s \\
(\mathrm{~N} / \mathrm{m})\end{array}$ & $\stackrel{n}{-}$ & $\begin{array}{c}T \\
\left({ }^{\circ} \mathrm{C}\right)\end{array}$ & $\begin{array}{c}G_{\mathrm{FE}} \\
(\mathrm{N} / \mathrm{m})\end{array}$ & $\begin{array}{c}s \\
(\mathrm{~N} / \mathrm{m})\end{array}$ & $\stackrel{n}{-}$ \\
\hline$\overline{\mathrm{C} 25[1]}$ & -35 & 141 & 15 & 5 & & & & & +20 & 107 & 10 & 5 \\
\hline $\mathrm{C} 40[1]$ & -35 & 178 & 37 & 5 & & & & & +20 & 100 & 9 & 5 \\
\hline $\begin{array}{r}\mathrm{C} 40 \mathrm{~A}[2] \\
\mathrm{B}[2] \\
\mathrm{C}[2]\end{array}$ & $\begin{array}{l}-24 \\
-24 \\
-24\end{array}$ & $\begin{array}{l}200 \\
163 \\
219\end{array}$ & $\begin{array}{l}29 \\
17 \\
22\end{array}$ & $\begin{array}{l}5 \\
3 \\
6\end{array}$ & & & & & $\begin{array}{l}+20 \\
+20\end{array}$ & $\begin{array}{l}84 \\
94 \\
-\end{array}$ & $\begin{array}{r}7 \\
20\end{array}$ & $\begin{array}{l}4 \\
3 \\
-\end{array}$ \\
\hline $\begin{array}{r}\text { LC45D [3] } \\
W[3]\end{array}$ & $\begin{array}{l}-30 \\
-30\end{array}$ & $\begin{array}{l}94 \\
95\end{array}$ & $\begin{array}{l}11 \\
23\end{array}$ & $\begin{array}{l}6 \\
4\end{array}$ & $\begin{array}{l}-15 \\
-15\end{array}$ & $\begin{array}{l}54 \\
55\end{array}$ & $\begin{array}{l}7 \\
4\end{array}$ & $\begin{array}{l}3 \\
4\end{array}$ & $\begin{array}{l}+20 \\
+20\end{array}$ & $\begin{array}{l}45 \\
46\end{array}$ & $\begin{array}{l}2 \\
2\end{array}$ & $\begin{array}{l}3 \\
3\end{array}$ \\
\hline $\begin{array}{r}\mathrm{C} 100 \mathrm{D}[4] \\
\mathrm{W}[4]\end{array}$ & $\begin{array}{l}-30 \\
-30\end{array}$ & $\begin{array}{l}168 \\
134\end{array}$ & $\begin{array}{r}23 \\
5\end{array}$ & $\begin{array}{l}3 \\
4\end{array}$ & $\begin{array}{l}-15 \\
-15\end{array}$ & $\begin{array}{l}155 \\
117\end{array}$ & $\begin{array}{r}2 \\
17\end{array}$ & $\begin{array}{l}3 \\
4\end{array}$ & $\begin{array}{l}+18 \\
+18\end{array}$ & $\begin{array}{r}139 \\
91\end{array}$ & $\begin{array}{r}5 \\
23\end{array}$ & $\begin{array}{l}3 \\
4\end{array}$ \\
\hline
\end{tabular}

The cement paste becomes more dense and the concrete more homogeneous. In that concrete fewer stress concentration occurs. The cracking will therefore not be so extensive during fatigue loading. Another explanation is that the cracks in the ice are healed during the unloading cycles when compressive stresses are active.

For ordinary temperature the fatigue life length is sometimes written as $[12,13]$

$$
\log N=C \frac{1-S_{\max }}{1-S_{\min } / S_{\max }}
$$

or rearranged as

$$
S_{\max }=1-\frac{1}{C}\left(1-\frac{S_{\min }}{S_{\max }}\right) \log N
$$

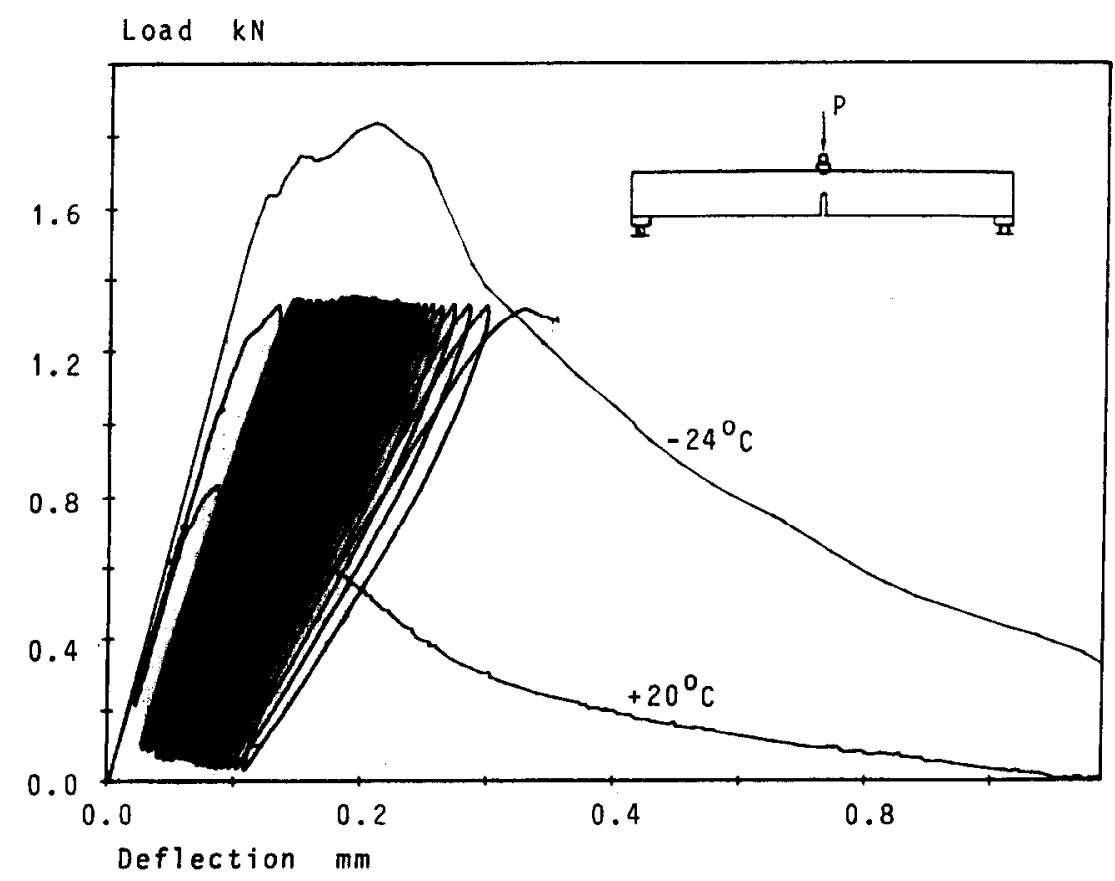

Fig. 4. Load-deformation curves for $\mathrm{C} 40$ at varying temperatures[2, 6]. 
Table 5. Fatigue tests

\begin{tabular}{|c|c|c|c|c|c|c|c|c|}
\hline \multirow[b]{2}{*}{$\begin{array}{l}\text { Test } \\
\text { No. }\end{array}$} & \multicolumn{4}{|c|}{$-24^{\circ} \mathrm{C}$} & \multicolumn{4}{|c|}{$+20^{\circ} \mathrm{C}$} \\
\hline & $\begin{array}{c}\text { Batch } \\
\text { No. }\end{array}$ & $\begin{array}{l}P_{\max } \\
(\mathbf{N})\end{array}$ & $P_{\max } / P_{0}$ & $\underline{N}$ & $\begin{array}{c}\text { Batch } \\
\text { No. }\end{array}$ & $\begin{array}{l}P_{\max } \\
(\mathrm{N})\end{array}$ & $\begin{array}{c}P_{\max } / P_{0} \\
-\end{array}$ & $\stackrel{N}{-}$ \\
\hline 1 & A & 1412 & 85 & 120 & $\mathrm{~A}$ & 808 & 92 & 12 \\
\hline 2 & B & 1412 & 85 & 50,150 & A & 803 & 92 & 26 \\
\hline 3 & A & 1412 & 85 & $>25,000$ & B & 750 & 86 & 89 \\
\hline 4 & B & 1412 & 85 & 16,707 & A & 750 & 86 & 102 \\
\hline 5 & A & 1578 & 95 & 12,244 & B & 745 & 85 & $>55$ \\
\hline 6 & B & 1661 & 100 & 1 & B & 745 & 85 & 81 \\
\hline 7 & A & 1661 & 100 & 33 & A & 745 & 85 & 32 \\
\hline 8 & B & 1578 & 95 & $>22,345$ & B & 723 & 83 & 293 \\
\hline 9 & B & 1661 & 100 & $>15,384$ & B & 709 & 81 & 638 \\
\hline 10 & B & 1661 & 100 & 1 & $\mathrm{~A}$ & 704 & 80 & 530 \\
\hline 11 & A & 1661 & 100 & 1 & & & & \\
\hline 12 & B & 1628 & 98 & 108 & & & & \\
\hline 13 & $\mathrm{C}$ & 1618 & 90 & 1,919 & & & & \\
\hline 14 & C & 1618 & 90 & 101 & & & & \\
\hline 15 & C & 1618 & 90 & $>215$ & & & & \\
\hline 16 & $\mathrm{C}$ & 1618 & 90 & 4 & & & & \\
\hline 17 & C & 1618 & 90 & 4 & & & & \\
\hline 18 & $\mathrm{C}$ & 1618 & 90 & 2,317 & & & & \\
\hline 19 & C & 1618 & 90 & 401 & & & & \\
\hline
\end{tabular}

$N=$ number of cycles before failure.

where

$N=$ number of loadings to failure,

$C=$ coefficients depending on environment and stress conditions. Normal values range between 10 and 20 ,

$S_{\max }=\sigma_{\max } /\left(k_{1} f_{\mathrm{ck}}\right)$,

$S_{\min }=\sigma_{\min } /\left(k_{1} f_{\mathrm{ck}}\right)$,

$\sigma_{\max }=$ maximum stress,

$\sigma_{\min }=$ minimum stress,

$f_{\mathrm{ck}}=$ concrete strength,

$k_{1}=$ reduction coefficient to be used in design codes.

For concrete in tension or compression or subjected to stress reversals at normal temperatures Tepfers has proposed $C=14.6(1 / C=0.0685)[12,14]$. Using this value and $P_{\max } / P_{0}$,

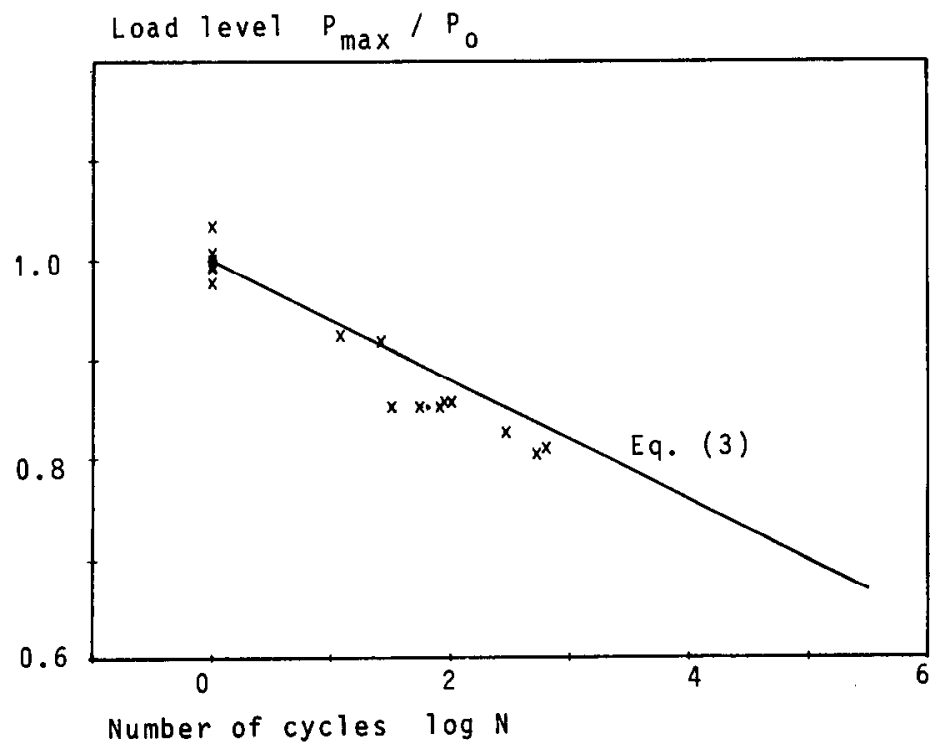

Fig. 5. Cyclic beam tests at $+20^{\circ} \mathrm{C}[2]$. 


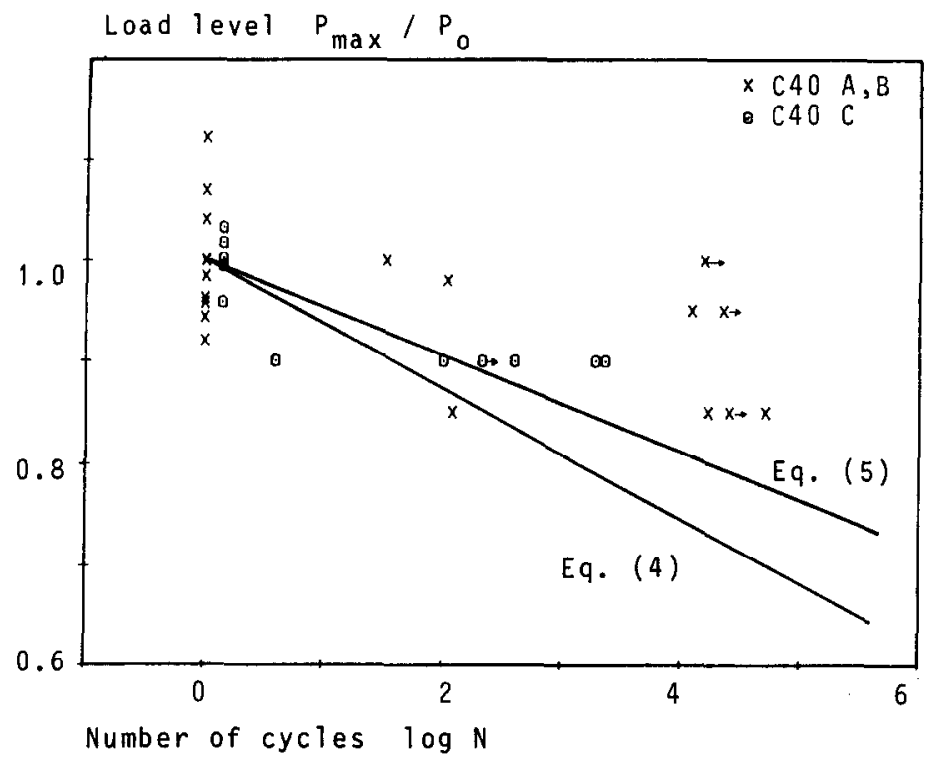

Fig. 6. Cyclic beam tests at $-24^{\circ} \mathrm{C}[2]$.

$P_{\min } / P_{0}$ instead of $S_{\max }$ and $S_{\min }$ we obtain with eq. (2) the following expression when $P_{\min } / P_{\max }=0.1 \mathrm{kN} / 0.8 \mathrm{kN}=0.125$ :

$$
P_{\max } / P_{0}=1-0.0685(1-0.125) \log N=1-0.060 \log N .
$$

This line has been drawn in Fig. 5 and it gives a fairly good correspondence with the tests at $+20^{\circ} \mathrm{C}$. that

For the tests at $-24^{\circ} \mathrm{C}$ we obtain in the same way with $P_{\min } / P_{\max }=0.1 \mathrm{kN} / 1.6 \mathrm{kN}=0.0625$

$$
P_{\max } / P_{0}=1-0.0685(1-0.0625) \log N=1-0.064 \log N \text {. }
$$

This line has been drawn in Fig. 6. However it seems to be too conservative. A higher value of $C$ is called for. With $C=20$ we obtain

$$
P_{\max } / P_{0}=1-\frac{1}{20}(1-0.0625) \log N=1-0.047 \log N .
$$

This line has also been drawn in Fig. 6 and it gives a better correspondence with the test results.

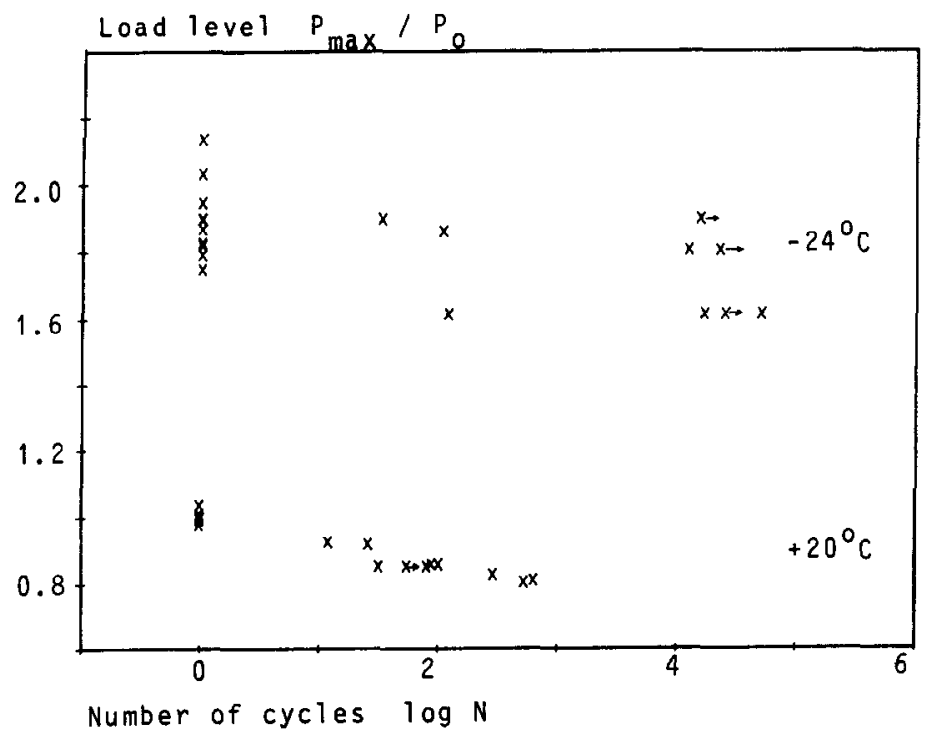

Fig. 7. Cyclic beam tests at $+20^{\circ} \mathrm{C}$ and $-24^{\circ} \mathrm{C}$ referred to static peak load $P_{0}$ at $+20^{\circ} \mathrm{C}[2]$. 


\section{DISCUSSION AND CONCLUSIONS}

For concretes with a high moisture content both the experimentally determined fracture energy $G_{\mathrm{FE}}$ and the fatigue strength are increased when the temperature is lowered from +20 to $-30^{\circ} \mathrm{C}$. This is probably due to a contribution from the ice that is formed in the concrete. The positive effect may be reduced by repeated freeze-thaw cycles and the combined effect of fatigue loading and freeze-thaw cycles ought to be studied.

\section{REFERENCES}

[1] Marit Brusdal and Thomas Krekula, Steel fibre reinforced concrete. Three point bending tests with different types of fibres and concrete at $+20^{\circ} \mathrm{C}$ and $-35^{\circ} \mathrm{C}$. (In Swedish with a summary in English.) Division of Structural Engineering, Luleå University of Technology, Diploma Work 1987:01E, Luleå (1987).

[2] Ulf Ohlsson, Fatigue strength of unreinforced concrete. Tests in $20^{\circ} \mathrm{C}$ and $-24^{\circ} \mathrm{C}$. Division of Structural Engineering, Luleå University of Technology, Research report TULEA 1988:00X, to be published.

[3] Kurt Solaas and Dag Brox Rindahl, Fracture energy of high-strength lightweight concrete under different temperatures and moistures. (In Swedish with a summary in English.) Division of Structural Engineering, Luleå University of Technology, Diploma Work 1987:28E, Luleå (1987).

[4] Göran Wallgren, Fracture energy of high-strength concrete under different temperatures and moistures. (In Swedish with a summary in English.) Division of Structural Engineering, Luleå University of Technology, Diploma Work 1987:36E, Luleå (1987).

[5] Stig Alvestad and Knut Aune Jørgensen, Fracture energy in high strength lightweight concrete with reference to freeze-thaw cycles. (In Swedish with a summary in English.) Division of Structural Engineering, Luleå University of Technology, Diploma Work 1987:160E, Luleå (1987).

[6] Lars Andersson, Fatigue strength of unreinforced concrete at $+20^{\circ} \mathrm{C}$ and $24^{\circ} \mathrm{C}$. (In Swedish with a summary in English.) Division of Structural Engineering, Luleå University of Technology, Diploma Work to be published.

[7] Per Anders Daerga, Properties of hardened concrete at low temperatures. A literature review. Division of Structural Engineering, Luleå University of Technology. Research Report TULEA 1988:007.

[8] RILEM TC 50-FMC, Determination of the fracture energy of mortar and concrete by means of three-point bend tests on notched beams. RILEM draft recommendation. Mater. Struct. 18, 285-290 (1985).

[9] C. van der Veen, Properties of concrete at very low temperatures. A survey of the literature. Steven Report 25-87-2, Delft University of Technology, Delft (1987).

[10] Manuel Elices, Jaime Planas and P. Maturana, Fracture of concrete at cryogenic temperatures. SEM/RILEM International Conference of Fracture of Concrete and Rock, pp. 159-169, Houston, Texas (Edited by S. P. Shah and S. E. Swartz). Preprint, Society for Experimental Mechanics, Bethlehem, PA (1987).

[11] H. A. Körmeling, Strain rate and temperature behaviour of steel fibre concrete in tension. Doctoral Thesis, Delft University of Technology (1986) (Reference quoted from [9].)

[12] RILEM TC 36-RDL, Long term random dynamic loading of concrete structures. Mater. Struct. 17, 1-28 (1984).

[13] Rolf Lenschow, Fatigue of high strength concrete. Utilization of High Strength Concrete (Edited by Ivar Holand et al.), pp. 271-290. Tapir, Trondheim (1987).

[14] Ralejs Tepfers, Fatigue of plain concrete subjected to stress reversals. Paper SP 75-9 in Fatigue of Concrete Structures, pp. 195-215. ACI Publication SP-75, Detroit (1982). 